\title{
Diagnosis dan Penatalaksanaan Papiloma Laring Berulang pada Dewasa
}

\author{
Erwi Saswita ${ }^{1}$, Ade Asyari², Novialdi², Fachzi Fitri ${ }^{2}$
}

\begin{abstract}
Abstrak:
Pendahuluan: Papiloma laring merupakan tumor yang berasal dari infeksi Human Papiloma Virus (HPV) yang bersifat jinak, berulang dan berisiko berubah menjadi ganas. Anti virus yang diberikan seringkali tidak menyebabkan remisi dari papiloma sehingga perlu tindakan bedah yang berulang. Tujuan: Memahami cara menegakkan diagnosis dan melakukan tatalaksanaan papilloma laring berulang pada dewasa. Laporan Kasus: Dilaporkan satu kasus papiloma laring pada seorang pasien perempuan usia 26 tahun yang sudah dilakukan ekstirpasi papiloma dengan laser 5 tahun yang lalu. Pasien tidak pernah kontrol lagi sehingga dilakukan trakeostomi akibat obstruksi jalan napas. Penatalaksanaan selanjutnya adalah dengan pemberian antivirus dan tindakan bedah setiap 3 bulan untuk ekstirpasi papiloma. Kesimpulan: Papiloma laring dapat menginfeksi laring dan dapat tumbuh kembali dengan cepat dan jika dibiarkan dapat menyebabkan obstruksi jalan napas. Penatalaksanaan dengan antivirus dan penanganan bedah dilakukan berulang menggunakan mikrolaringoskopi ekstirpasi dengan Laser.
\end{abstract}

Kata kunci: Papiloma laring berulang, HPV, antivirus, mikrolaringoskopi ekstirpasi.

\begin{abstract}
Introduction: Laryngeal papilloma is a tumor originating from infection of Human Papilloma Virus (HPV), which are benign, recurrent and can transformation become malignant. Anti-virus is given often do not lead to remission of papilloma so necessary surgery can be done repeatedly. Objective: Understanding how to make diagnosis and management recurrent laryngeal papilloma in adults. Case report: It was reported one case of laryngeal papillomas in a female patient aged 26 years who had done extirpation papillomas with laser 5 years ago. Patients never control again so tracheostomy due to airway obstruction. Management are antiviral medicamentosa and surgery was done every three months to dispose of papilloma. Conclusion: Laryngeal papillomas can growth and can cause airway obstruction. Management of the antivirus and surgical treatment performed repeatedly using microlaringoscopy extirpation with Laser.
\end{abstract}

Keywords: recurrent laryngeal papilloma, human papilloma virus, antivirus, microlaringoscopy extirpation.

Affiliasi penulis : Bagian THTL-KL Fakultas Kedokteran Universitas Andalas, Korespondensi :1. Bagian THT-KL FK Unand 2. Bagian THT-KL FK Unand. JI.Perintis Kemerdekaan No.94 PO BOX 49 Padang 25127, email: erwieka@gmail.com, Telp\HP: 081363159179

\section{PENDAHULUAN}

Papiloma laring merupakan tumor jinak yang tampak sebagai kutil yang berbentuk soliter atau multipel yang dapat tumbuh disepanjang traktus respiratorius terutama laring dan trakea. Penyakit ini cenderung kambuh sehingga disebut juga recurrent respiratory papillomatosis dan dapat berubah menjadi ganas. ${ }^{1,2}$

Penyakit ini bisa terjadi pada anak dan dewasa. Pada anak paling sering dijumpai pada umur 2-4 tahun, sedangkan pada dewasa rata-rata usia 20-40 tahun. ${ }^{1-}$ 3,5 Papiloma laring sebenarnya kasus jarang pada dewasa. Di Amerika Serikat tercatat perbandingan kasus papiloma pada anak dibanding dewasa adalah 4,3 per 100.000 anak dibanding 1, 8 per 100.000 dewasa..$^{1,2,4,5}$

Penyakit ini disebabkan oleh infeksi Human Papilloma Virus (HPV). ${ }^{1,2,4,5}$ Ada sekitar 200 jenis tipe HPV yang ada, dimana tipe HPV 6 dan HPV 11 adalah virus yang sering ditemukan pada papiloma laring. 1,2,4,5 HPV 16 dan HPV 18 ditemukan pada papiloma laring yang telah bertransformasi menjadi ganas. ${ }^{6-8}$

Seringnya kekambuhan papiloma ini telah menimbulkan masalah tersendiri dari segi ekonomi. Di Amerika Serikat data menunjukkan dibutuhkan lebih dari $\$ 100$ juta pertahun untuk menangani 15.000 kasus tindakan operasi. Beberapa studi menunjukkan HPV 11 menunjukkan agresifitas dari penyakit dimana akan sering membutuhkan penanganan bedah. ${ }^{1,2}$

\section{PATOFISIOLOGI}

Papiloma laring merupakan penyakit yang jarang. Tempat yang paling sering terinfeksi adalah daerah laring terutama pita suara. Papiloma laring adalah tumor yang bersifat jinak, sering kambuh dan cenderung berubah menjadi ganas. Penyebab penyakit ini adalah human papilloma virus (HPV). ${ }^{1,2,3}$

Terdapat lebih dari 150 tipe HPV yang sudah diketahui. Ada 3 klasifikasi HPV yang terbagi atas risiko onkogenik rendah, risiko onkogenik sedang dan risiko onkogenik tinggi. ${ }^{11,12}$

Resiko onkogenik rendah diantaranya HPV tipe 6, 11, 42, 43 dan 44 berhubungan dengan lesi derajat rendah. Resiko onkogenik sedang diantaranya HPV 
tipe 33, 35, 51 dan 52 berhubungan dengan lesi derajat sedang kecenderungan untuk menetap dan jarang menjadi progresif. Sedangkan risiko onkogenik tinggi diantaranya HPV tipe 16, 18, 31, 39, 45, 46, 58 dan 59 ditemukan pada lesi derajat tinggi dan karsinoma in situ. ${ }^{11,12}$

Penyebaran HPV masih belum jelas. Tipe juvenil diduga transmisi pada saat peripartum dari seorang ibu yang terinfeksi virus ini. Pada orang dewasa, cara transmisi virus dengan cara orogenital kontak seksual. Sebuah studi kasus memperlihatkan penderita papiloma laring pada dewasa terjadi pada masa seksual aktif. Frekuensi papiloma laring juga tinggi pada penderita yang sering melakukan oral genital kontak seksual. ${ }^{1-12}$

HPV tipe 6 dan 11 paling sering ditemukan pada kasus papiloma laring, sedangkan tipe 16 dan 18 lebih jarang. Studi sebelumnya menyatakan tipe HPV berperan dalam mempengaruhi bentuk klinis dari papiloma. HPV tipe 11 memperlihatkan agresifitas dari lesi. HPV tipe 16 dan 18 memperlihatkan kecenderungan untuk bertransformasi menjadi ganas. ${ }^{8}$

\section{HISTOPATOLOGI}

Papiloma menunjukkan cabang-cabang fibrovaskular seperti jari-jari tangan yang dikelilingi oleh lapisan epithelium well - differentiated stratified squamous yang tebal yang sering parakeratotik pada permukaannya. (Gambar 2). Mitosis dan focal keratosis sering dijumpai. Squamous metaplasia, dysplasia atau squamous cell merupakan tanda - tanda akan adanya keganasan.

\section{GEJALA KLINIS}

Gejala klinis yang timbul tergantung pada letak dan besarnya tumor. Biasanya penderita datang dengan suara serak. Jika diagnosis terlambat papiloma dapat tumbuh menyebabkan afonia dan obstruksi jalan napas (Gambar 3). Gejala yang paling sering dijumpai adalah perubahan suara. Suara serak merupakan gejala dini dan keluhan yang paling sering dikemukakan

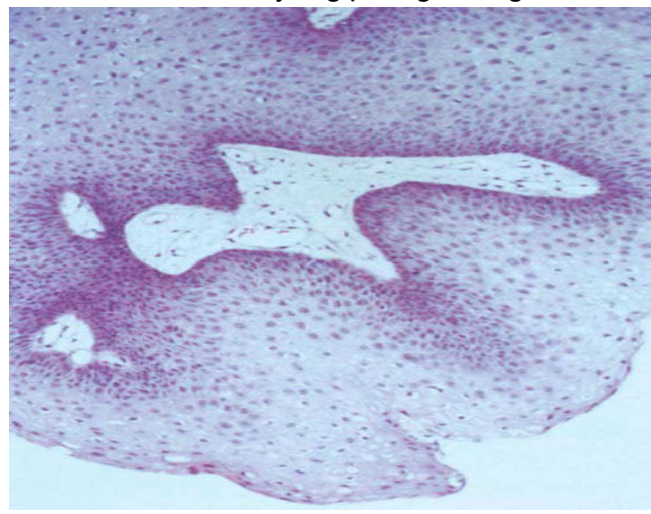

Gambar 2. Histopatologi dari papiloma memperlihatkan gambaran epitel berlapis nonkeratin seperti jari. ${ }^{1}$

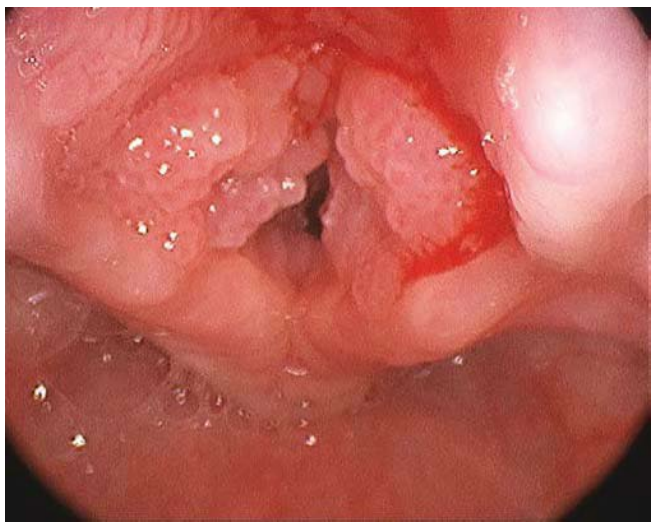

Gambar 3. Papiloma menutupi laring ${ }^{1}$

apabila tumor tersebut terletak di pita suara. Papiloma laring dapat membesar, Kadang-kadang dapat mengakibatkan sumbatan jalan nafas yang mengakibatkan stridor dan sesak. Timbulnya sesak merupakan suatu tanda bahwa telah terjadi sumbatan jalan nafas bagian atas dan biasanya diperlukan tindakan trakeostomi. $^{1-6,8}$

\section{DIAGNOSIS}

Diagnosis dapat ditegakkan berdasarkan:1,6

\section{Anamnesis}

Adanya suara parau sampai afonia.

2. Gejala klinis

Suara serak merupakan gejala yang paling sering dikeluhkan. Pada papilloma yang besar bisa terjadi stridor sampai sesak nafas.

3. Pemeriksaan

- Laringoskopi direk. dan indirek.

- $\quad$ Flexible fibreoptic nasopharyngoscopy.

- Biopsi dan pemeriksaan histopatologi.

\section{PENATALAKSANAAN}

Tidak ada modalitas tunggal yang efektif untuk eradikasi papiloma laring. Tujuan terapi papilloma laring adalah mempertahankan jalan nafas dan menghilangkan massa papiloma. .,2,4,6 $^{-1}$

Pengobatan utama papiloma laring adalah membuang tumor secara bedah mikrolaring dengan alat-alat operasi yang konvensional atau alat-alat yang canggih seperti Laser dan mikrodebrider dan terapi ajuvant. Di luar negeri penggunaan Laser lebih sering dilakukan untuk mengatasi penyakit ini, karena ketepatan pemotongan dan kontrol hemostatik yang lebih baik ${ }^{1,13,14}$

Penggunaan Laser mempunyai banyak keuntungan dibandingkan dengan pembedahan konvensional. Keuntungan Laser adalah ketepatan dengan tingkat keakuratan pembedahan dapat mencapai $0,1 \mathrm{~mm}$, dapat menghentikan perdarahan, mengurangi edema pasca operasi. Kerugiannya dapat menyebabkan kornea mata terbakar, dan untuk mengatasinya tenaga medis harus memakai kacamata pelindung (gogle), dan pasien memakai kassa basah sebagai pelindung mata. ${ }^{13,14}$ 
Beberapa terapi medis telah dicoba sebagai terapi ajuvan pada papiloma respiratorius rekuren. Efektivitas aktual dari setiap laporan terapi medis untuk papiloma respiratorius rekuren adalah sulit untuk ditentukan karena agresivitas yang mendasari penyakit ini kurang dipahami. Kriteria untuk mendapatkan terapi ajuvan adalah berdasarkan agresifitas papiloma yang membutuhkan lebih dari empat kali penanganan bedah pertahun, rekuren, tumbuh pada daerah distal dari traktus respiratorius. ${ }^{1,5}$

\section{PROGNOSIS}

Penanganan bedah pada dewasa seringkali harus dilakukan berulang, tetapi ada suatu kondisi dimana setelah tindakan bedah dilakukan, penyakit akan regresi spontan. Oleh karena itu monitoring dan dokumentasi harus tetap dilakukan agar agresifitas penyakit dapat diamati. 1,2,5

\section{LAPORAN KASUS}

Seorang pasien perempuan usia 26 tahun MR 680564 datang ke IGD RSUP Dr. M. Djamil Padang tanggal 22 Mei 2015 dengan keluhan utama sesak napas yang makin bertambah sejak 1 hari sebelum masuk rumah sakit. Suara serak yang bertambah berat sejak 4 tahun yang lalu dan dirasakan makin bertambah serak sejak 1 tahun terakhir. Rasa mengganjal di tenggorok ada, nyeri menelan tidak ada, susah menelan tidak ada, bengkak di leher tidak ada, riwayat batuk-batuk lama tidak ada, penurunan berat badan ada, demam tidak ada, riwayat merokok tidak ada. Riwayat kontak orogenital dengan lawan jenis ada. Pasien adalah lulusan perguruan tinggi negeri di Padang dan bekerja sebagai staf tata usaha di Sekolah Menengah Pertama di Solok Selatan.

Pasien sudah pernah menjalani operasi papiloma laring tahun 2010 dan kambuh 2 bulan kemudian. Pasien dianjurkan untuk operasi tapi pasien menolak. Pasien selama ini berobat tradisional.

Satus generalis keadaan umum tampak sesak, kesadaran komposmentis, frekuensi nafas 30 kali permenit, frekuensi nadi 84 kali permenit, tekanan darah $120 / 80 \mathrm{mmHg}$, suhu $36,7^{\circ} \mathrm{C}$. Pada pemeriksaan fisik: Toraks tampak retraksi pada suprasternal, epigastrium, stridor inspirasi, ronkhi (-), wheezing (-).

Pemeriksaan telinga kanan dan kiri, liang telinga lapang, membran timpani utuh, reflek cahaya (+). Pemeriksaan hidung: rinoskopi anterior dan rinoskopi posterior dalam batas normal. Pemeriksaan tenggorok didapatkan arkus faring simetris, uvula ditengah, tonsil T1-T1 tenang, dinding posterior faring tenang.

Pada laringoskopi indirek dan telelaringoskopi didapatkan epiglotis tenang, aritenoid tenang, tampak massa bergranul dengan permukaan licin dan hiperemis $(+)$ yang menutupi rima glotis, plika vokalis dan ventrikularis sukar dinilai secara keseluruhan, rima glotis hanya terbuka di $1 / 3$ posterior, sinus piriformis standing sekresi (-/-). Tidak terdapat pembesaran kelenjar getah bening.
Pemeriksaan analisa gas darah didapatkan kesan asidosis respiratorik. Pasien didiagnosis kerja dengan obstruksi jalan napas grade II et causa suspek papiloma laring berulang. Dengan diagnosis banding keganasan pada laring.

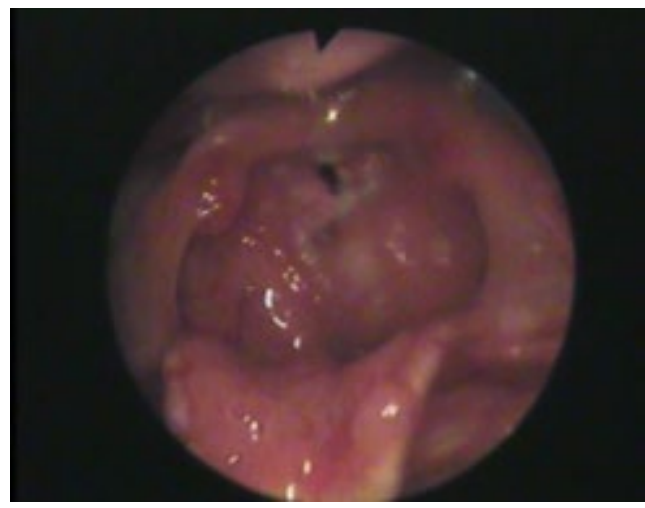

Gambar 4. Foto laring pasien

Pasien direncanakan untuk dilakukan trakeostomi emergensi hari itu juga dalam lokal anastesi dan direncanakan biopsi ekstirpasi dengan Micro Laryngoscopy Kleinsasser (MLC) dalam anestesi umum secara elektif pada tanggal 27 Mei 2015. Dilakukan pemeriksaan laboratorium darah rutin PT, APTT dengan kesan dalam batas normal. Pasien sebelumnya sudah dilakukan pemeriksaan Rontgen toraks pada tanggal 19 Mei 2015 didapatkan hasil cor dan pulmo dalam batas normal.

Pasien tidur telentang di meja operasi dalam lokal anastesia. Dilakukan tindakan aseptik antiseptik sekitar lapangan operasi. Dilakukan penandaan dan infiltrasi dengan lidokain. Insisi pada 2 jari batas bawah kartilago krikoid sampai ke suprasternal notch. Jaringan fascia , kutis, subkutis dibebaskan dengan klem tumpul lapis demi lapis sampai terlihat cincin trakea. Aspirasi terlihat udara pada Sulfas Atropin. Insisi trakea 2-3 untuk membuat stoma, masukkan kanul trakeostomi, kembangkan cuff, masukkan anak kanul dan fiksasi kanul. Operasi selesai.

Pada tanggal 27 Mei 2015 dilanjutkan dengan biopsi massa dengan MLC dalam anastesi umum. Gigi dilindungi dengan mouthguard dan dipasang MLC Kleinsasser. Laringoskop Kleinsasser dimasukkan posisi tegak lurus sampai nampak uvula, laringoskop terus dimasukkan sambil kepala ekstensi dan terlihat epiglotis, laringoskop diselipkan di bawah epiglotis sehingga tampak pita suara. Dilakukan fiksasi Kleinsasser. Tampak massa bergranul dengan permukaan licin, hiperemis (+) menutupi rima glotis, plika vokalis dan ventrikularis sukar dinilai secara keseluruhan, massa diambil secukupnya dengan forsep biopsi. Laringoskop Kleinsasser diangkat. Operasi selesai. Pasien diberikan terapi injeksi seftriakson 2x1 gram (iv), injeksi deksametason $3 \times 1$ ampul (iv), ambroksol sirup 3x2 sendok teh.

Follow up hari ketiga pasca operasi, darah keluar dari mulut tidak ada, nyeri tenggorok tidak ada, sesak nafas tidak ada, demam tidak ada. Batuk tidak ada, 
mual muntah tidak ada. Pada pemeriksaan fisik didapatkan keadaan umum sedang, tekanan darah $120 / 80 \mathrm{mmhg}$, nadi $86 x$ permenit, nafas $18 x$ /menit, suhu $36,8^{\circ} \mathrm{C}$. Pemeriksaan Telinga, hidung dan tenggorok dalam batas normal.

Pasien didiagnosis post biopsi papiloma laring diagnosis banding dengan keganasan pada laring . Diberikan terapi injeksi seftriakson 2x1 gram (iv), injeksi deksametason $3 \times 1$ ampul (iv), ambroksol syrup $3 \times 2$ sendok teh dan diperbolehkan pulang.

Pasien kontrol pada tanggal 19-6-2015 dengan membawa hasil Patologi Anatomi (PA) dengan nomor PJ 1022-15 dengan kesan: papiloma dengan displasia sedang berat dengan adanya komponen sel yang mencurigakan suatu keganasan.

Selanjut dilakukan Computerized Tomography Scanning (CT Scan) dimana tidak tampak tanda-tanda destruksi pada kartilago dan tidak ada pembesaran kelenjar getah bening pada leher. Kesan tampak massa pada daerah glotis. (Gambar 5).

Pasien didiagnosis dengan papiloma laring rekuren dan direncanakan untuk dilakukan ekstirpasi biopsi $M L C$ dengan Laser

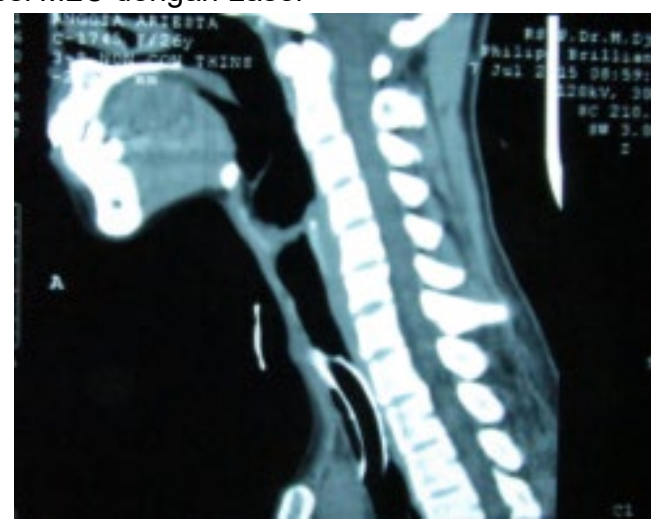

Gambar 5. Massa pada daerah glotis

Pada tanggal 19 September 2015 dilakukan operasi biopsi ekstirpasi $M L C$ dengan menggunakan laser. Operasi dimulai dengan pasien tidur telentang di meja operasi dalam narkose umum. Dilakukan pemasangan laringoskop Kleinsasser sehingga struktur laring dapat diidentifikasi. Tampak massa papil yang menutupi plika vokalis dekstra dan sinistra, epiglotis dan aritenoid sinistra. Selanjutnya, dilakukan biopsi pada massa di plika vokalis dekstra dan sinistra, dilanjutkan dengan ekstirpasi menggunakan forsep dan laser.

Pasca ekstirpasi pasien dirawat selama tiga hari dan diberikan terapi injeksi sefoperazon $2 \times 1 \mathrm{gr}$ (iv) dan injeksi dexamethasone $2 \times 1$ amp (iv) untuk satu hari. Pasien kontrol paska operasi pada tanggal 28 September 2015 dengan mengatakan nyeri menelan sudah berkurang sejak sesudah operasi. Pasien sudah makan dan minum seperti biasa. Keluhan lain tidak dirasakan pasien. Dari pemeriksaan laringoskopi tidak langsung dengan kaca laring dan telelaringoskopi tidak tampak gambaran massa pada epiglotis, plika vokalis dan aritenoid. Pasien membawa hasil dengan nomor PJ
1574-15 dengan jawaban diagnosis papiloma laring. (gambar 6).

Pasien diberi terapi dengan tablet asiklovir $5 \times 800$ mg. Pasien dianjurkan untuk kontrol setiap 2 minggu untuk evaluasi keadaan laring.

Pasien kontrol tanggal 13 Oktober 2015. Pada anamnesa keluhan tidak ada, sesak nafas tidak ada, nyeri dada tidak ada dan mual-muntah tidak ada. Pada regio colli anterior kanul trakeostomi terpasang baik dan passase udara lancar.

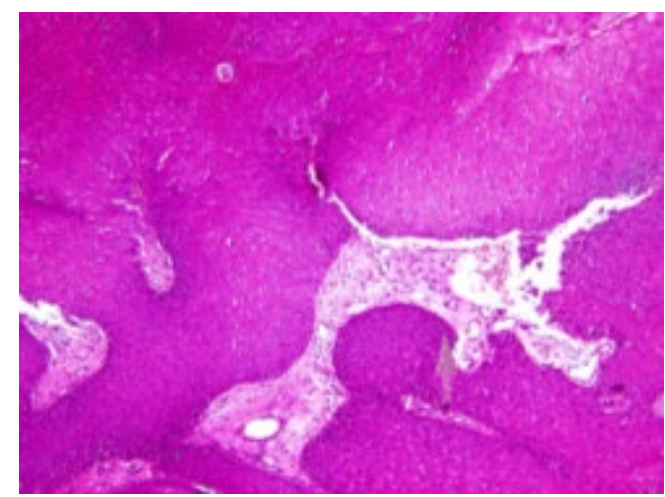

Gambar 6. Gambaran jaringan epitel yang membentuk papil-papil

Pada laringoskop indirek dan telelaringoskopi didapatkan epiglotis tenang, aritenoid tenang, plika vokalis dan ventrikularis pergerakan simetris, rima glotis terbuka, sinus piriformis standing sekresi -/-. Tidak ada massa. (Gambar 7). Pasien diterapi dengan asiklovir $5 \times 800 \mathrm{mg}$

Kontrol selanjutnya tanggal 27 Oktober 2015 pasien mengeluhkan batuk berdahak, sesak nafas tidak ada, nyeri dada tidak ada demam tidak ada dan mualmuntah tidak ada

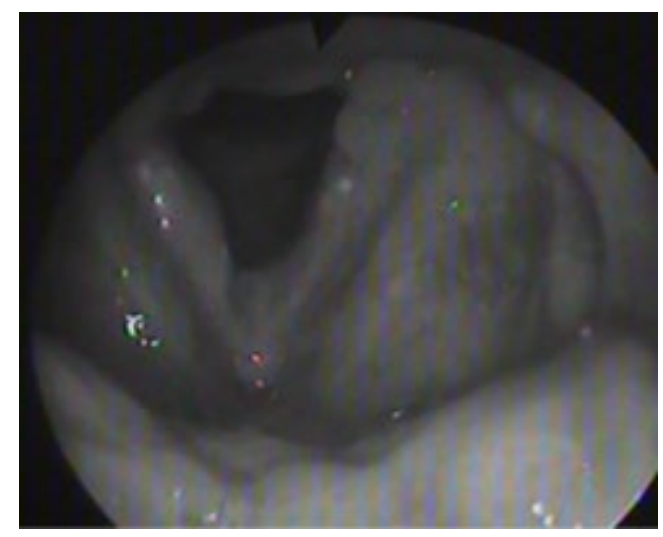

Gambar 7. Gambaran laring pasien satu bulan post operasi ektirpasi biopsi pailoma laring

Pada regio colli anterior kanul trakeostomi terpasang baik dan passase lancar. Pemeriksaan laringoskop incii $i k$ dan telelaringoskopi didapatkan epiglotis tampak massa berpapil, aritenoid tenang, tampak massa papil di plika vokalis kanan dan kiri, gerakan plika vokalis dan ventrikularis simetris, rima glotis terbuka, sinus piriformis standing sekresi -/.(Gambar 8). 


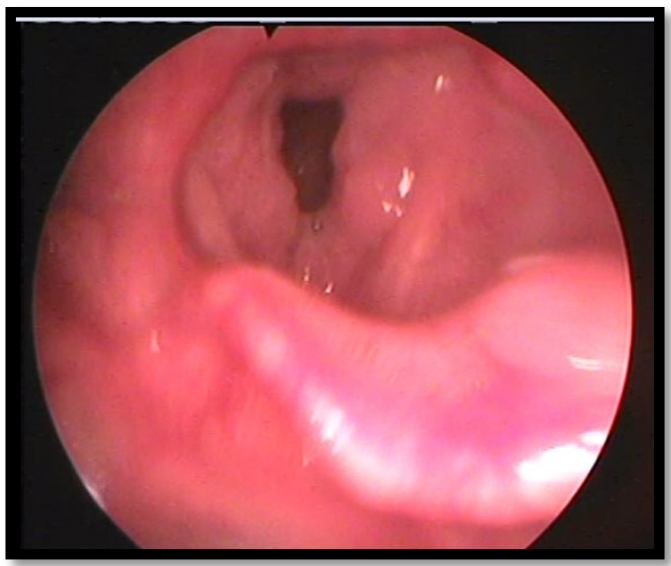

Gambar 8. Gambaran laring pasien 2 bulan post operasi ektirpasi biopsi pailoma laring

Pasien diberikan terapi Amoksisilin klavulanat $3 \times 625 \mathrm{mg}$, ambroksol 3x1 tablet dan asiklovir 5x800 mg. Pasien dianjurkan kontrol 2 minggu lagi dan akan dilakukan ekstirpasi papiloma 3 bulan lagi.

Pemeriksaan terhadap jenis genotype DNA HPV dilakukan pada tanggal 13 November 2015 di laboratorium di Jakarta. Hasil yang didapatkan tidak terdeteksinya virus HPV baik high risk maupun low risk HPV.

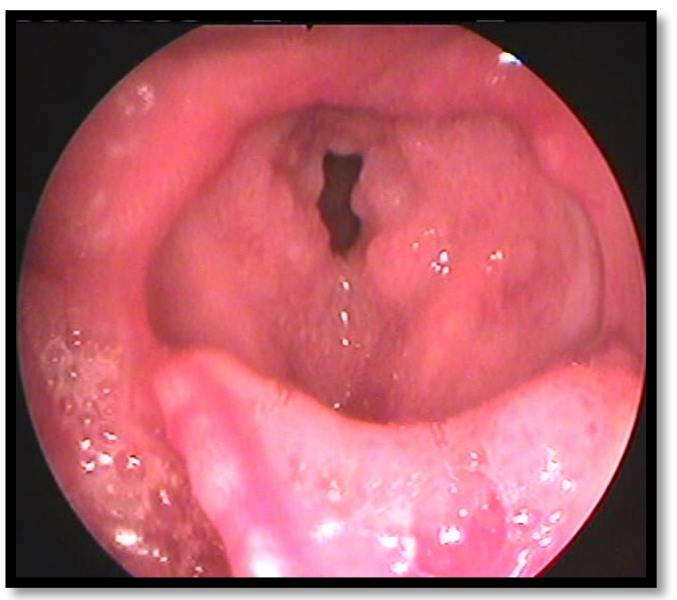

Gambar 9. Gambaran laring pasien 3 bulan post operasi ektirpasi biopsi pailoma laring

Pasien direncanakan untuk ektirpasi ulang papiloma dengan Laser.

\section{DISKUSI}

Dilaporkan satu kasus papiloma laring berulang pada pasien perempuan usia 26 tahun. Pasien telah didiagnosis dengan papiloma laring berulang sejak tahun 2010. Pasien sudah disarankan untuk operasi tapi kemudian pasien menolak. Setelah itu pasien tidak pernah kontrol lagi dan hanya berobat tradisional. Pasien datang tahun 2015 dengan keluhan sesak napas hebat. Pasien dilakukan pemasangan trakeostomi di IGD karena obstruksi jalan napas grade II.

Hal ini sesuai dengan literatur yang menyatakan papiloma cenderung kambuh dan cenderung menyebar. Paliloma bersifat jinak tapi dapat menyebabkan angka kesakitan dan kematian akibat obstruksi jalan napas atas. ${ }^{1-6,8}$

Karakteristik papiloma laring pada dewasa menurut literatur tidak seagresif pada anak. Papiloma laring dewasa biasanya berada pada umur 20-40 tahun dimana laki-laki lebih tinggi dibanding wanita dan sosioekonomi rendah lebih tinggi dibandingkan sosioekonomi tinggi. ${ }^{1,15}$ Berbeda dengan pasien ini, pasien adalah wanita berumur 26 tahun pasien tamatan perguruan tinggi yang bekerja sebagai staf sebuah sekolah menengah umum di daerah.

Walaupun papiloma dapat tumbuh dimana saja disepanjang traktus respiratorius atas dan bawah, laring merupakan tempat predileksi tersering tumbuhnya papiloma terutama pada plika vokalis. ${ }^{1-}$ $4,6,8,15$ Sama halnya pada kasus ini dimana papiloma terletak pada daerah plika vokalis dan epiglotis.

Etiologi terbanyak dari papiloma laring disebabkan oleh dua tipe dari HPV yaitu HPV 6 dan HPV 11. Dua tipe virus ini juga didapatkan pada genital. Infeksi dari HPV pada dewasa biasanya merupakan penyakit menular seksual. Manifestasi klinis dari HPV pada genital adalah berupa kondiloma akuminata pada serviks dan vulva pada wanita dan penis dan anus pada pria ${ }^{1,2}$. Walaupun banyak literatur yang menyatakan belum mengetahui pasti bagaimana virus ini menginfeksi tapi diyakini virus ini tertular melalui kontak seksual atau terlahir dari orang tua dengan genital papiloma. 1,2,6 Pada kasus ini pasien mengakui adanya kontak orogenital sebelum terdiagnosis papiloma laring, walaupun pasien menyatakan suara serak sudah ada sejak lama. Papiloma laring pada anak biasanya lebih bersifat agresif dan dapat berlanjut sampai usia dewasa. ${ }^{1}$

Karakteristik dari papiloma laring dapat terlihat pada pemeriksaan tipe dari virus. HPV 11 berhubungan dengan agresifitas pertumbuhan papiloma yang membutuhkan tindakan bedah. Sedangkan kecenderungan berubah menjadi ganas kurang dari $1 \%$. ${ }^{2,8}$ HPV jenis 16 dan HPV 18 sudah ditemukan pada Squamous cell carcinoma pada keganasan kepala dan leher. HPV ini akan menyebabkan perubahan sel papiloma menjadi sel kanker. ${ }^{8}$

Dalam keadaan normal suara dihasilkan karena adanya tekanan udara dari paru melewati dan menggetarkan pita suara. Ketika ada massa tumor di pita suara, suara yang keluar akan terdengar serak yang merupakan gejala yang umum pada papiloma laring. ${ }^{6}$ Sama halnya pada kasus ini keluhan yang pertama kali timbul adalah suara serak.

Tujuan penatalaksanaan papiloma laring adalah membuang secara menyeluruh papiloma laring dengan preservasi struktur normal. Metode yang dipakai untuk ekstirpasi papiloma adalah mikrodebrider atau dengan menggunakan bermacam Laser. ${ }^{13,14}$ Pada pasien ini digunakan mikrolaringoskopi Laser Diode yang mempunyai serat optic dan memiliki keuntungan yang bisa mengontrol perdarahan di daerah operasi, 
mengurangi edema pasca operasi dan bisa mempercepat waktu pemulihan. Hal ini sesuai dengan literatur bahwa salah satu keuntungan penggunaan Laser yaitu dapat memperpanjang periode bebas dari suatu penyakit. ${ }^{4,5}$

Penatalaksanaan ekstirpasi papiloma bisa dilakukan 4-5 kali dalam setahun dan pemberian ajuvan terapi dengan anti viral. Pada pasien ini sebenarnya telah dianjurkan untuk dilakukan ekstirpasi ulangan satu bulan setelah terdiagnosis kekambuhan dari papiloma pada tahun 2010. Pada saat sekarang kekambuhan terlihat setelah satu bulan dilakukan ekstirpasi papiloma dan pasien direncanakan dilakukan ektirpasi ulangan tiap 3 bulan dengan kanul trakeostomi terpasang untuk mencegah obstruksi jalan napas.

Pada pasien ini telah dilakukan pemeriksaan genotype dari $D N A$ jaringan yang telah disimpan dalam bentuk parafin blok dengan metode Polymerase Chain Reaction $(P C R)$. Hasil yang didapatkan adalah tidak terdeteksi adanya high risk HPV maupun low risk HPV.

Menurut Novel $\mathrm{dkk}^{16}$, ada beberapa pemeriksaan HPV yang berasal dari jaringan segar, bahan swab dan blok paraffin. PCR adalah salah satu pemeriksaan yang digunakan untuk mendeteksi ada atau tidaknya DNA HPV di dalam sel epitel yang dicurigai terinfeksi HPV. Infeksi virus ini bisa saja tidak terdeteksi pada pemeriksaan. DNA adalah molekul yang sangat sensitif terhadap panas. Sedangkan pembuatan parafin sendiri melalui tahap fiksasi sampai pelabelan membutuhkan suhu $58^{\circ} \mathrm{C} .{ }^{17}$

\section{SIMPULAN}

Papiloma laring pada dewasa merupakan kasus yang jarang dimana bersifat eksofitik, sering kambuh dan cenderung untuk menjadi ganas. Kekambuhan tumor pada kasus ini cukup cepat dimana satu bulan setelah dilakukan ekstirpasi pailoma telah tumbuh jaringan papiloma yang baru.

Pemasangan trakeostomi dilakukan untuk menjaga tidak terbuntunya jalan napas pada papiloma yang bersifat agresif. Tindakan bedah untuk ekstirpasi ulang papiloma direncanakan dilakukan tiap 3 bulan merupakan tindakan pilihan untuk papiloma laring. Tindakan bedah yang dipakai adalah menggunakan Laser dimana salah satu keuntungan dalam penggunaan laser adalah mengurangi perdarahan setelah dilakukannya tindakan bedah.

Pemeriksaan terhadap infeksi HPV dari blok parafin tidak ditemukan infeksi HPV. Terapi ajuvan paska ekstirpasi papiloma adalah pemberian antivirus seperti acyclovir walaupun kekambuhan papiloma tetap ada.

\section{DAFTAR PUSTAKA}

1. Derkay CS, Baldassari CM. Recurrent respiratory papillomatosis. In: Bailey BJ, Johnson JT, Head and Neck Surgery-Otolaryngology, $5^{\text {th }}$ edition. Philadelphia; Lipincott Williams and Wilkins Publishers; 2006.p.1409-27
2. Larson DA, Derkay CS. Epidemiology of recurrent respiratory papilomatosis. Journal Compilation APMIS. 2010.118: 450-4

3. Martina D, Kurniawan A, Pitoyo CW. Pulmonary papillomatosis: a Rare case of recurrent respiratory papillomatosis presenting with multiple nodular and cavitary lesions. Acta Med Indones-J Intern Med. 2014;46(3): 238-43

4. Zacharisen MC, Conley SF. Recurrent respiratory papillomatosis in children: masquerader of common respiratory diseases. pediatrics 2006;118 (5):1925-3

5. Boltezar IH, Bahar MS, Zargi M, Gale N, Maticic M, Poljak M. Adjuvant therapy for laryngeal papillomatosis. Acta Dermatoven APA .2011; 20(3).p.175-9

6. National Institutes of Health National Institute on Deafness and Other Communication Disorders. Recurrent respiratory papillomatosis or laryngeal papillomatosis. 2010; 10.

7. Suryatman A, Nuswantara S. Pemanfaatan metode berbasis hibridisasi DNA-RNA dalam mendeteksi human papilloma virus pada sampel jaringan. [Prosiding]. Jakarta: Universitas Terbuka; 2011. Available from http://repository.ut.ac.id./2269/. Diunduh pada Oktober 2016

8. Silverman DA, Pitman MJ. Current diagnosis and management trends for recurrent respiratory papillomatosis. Loppincot William \& Wilkin. 2004.12: 532-37

9. Woodson GE. Upper airway anatomy and function in: Bailey BJ, Johnson JT, Head and Neck SurgeryOtolaryngology, $5^{\text {th }}$ edition. Philadelphia; Lipincott Williams and Wilkins Publishers; 2006.p. 868-78

10. Sasaki CT, Kim YH. Anatomy of the larynx. In: Snow JB, Ballenger JJ, editor. Ballenger's Otorhinolaryngology Head and Neck Surgery. 17th ed. Philadelphia : Lea \& Febiger; 2009. 1090-109

11. Torente MC, Rodrigo JP, Haigentz M, Dikkers FG, Rinaldo $A$, et all. Human papillomavirus infections in laryngeal cancer. Head and Neck- DOI 2011.10.1002.p.581- 86

12. Fernandes JV, Fernandes TA. Human Papillomavirus: biology and pathogenesis. Dalam: Broeck DV, editor. Human Papillomavirus and Related Diseases. London: IntechOpen; 2012. Diunduh 25 Agustus 2014.

13. Gandhi S, Remacle M. Lasers in laryngology. Dalam: Kirtane MV, de Souza CE. Laryngology, Otorhinolaryngology - Head and Neck Surgery Series. Stutgart: Thieme; 2014. P.147-54.

14. Oswal V, Remacle M. Principles and practice of lasers in otorhinolaryngology and head and neck surgery. Netherlands: Kugler Publication; 2002. P.3-133.

15. Correia S, Dionisio J, da Costa JD. Recurrent respiratory papillomatosis of the airway: The experience of an endoscopic unit. Pnemologia. 
Portuguese journal of Pulmology. Elsevier. 2015: $21 ;(2): 82-9$

16. Novel SS, Safitri R, Nuswantara S. Perbandingan beberapa metode molekuler dalam uji DNA HPV (Human Papillomavirus). CDK 2011.186.Vol.38 (5).p. 356-8.

17. Santhoshkumar R, Santhosh R, Shibu B, Hareesh kumar H, Gayathri SS. A novel cold boat (cold plate) method to overcome the irregular solidification of paraffin wax during the time of preparation of blocks for microtomy. J Cytol Histol. 2014; S4:002. DOI: 10.4172/2157-7099.S4-002 .Cited January 2.2014. 